\title{
MUSKMELON SEED PRIMING IN RELATION TO SEED VIGOR
}

\author{
Warley Marcos Nascimento*; Fernando Antônio Souza de Aragão \\ Embrapa Hortaliças, C.P. 218 - 70359-970 - Brasília, DF - Brasil. \\ *Corresponding author 〈wmn@cnph.embrapa.br>
}

\begin{abstract}
A number of important factors may affect seed priming response, including seed quality. Effects of seed vigor on seed priming response were investigated using seed lots of two muskmelon (Cucumis melo L.) cultivars. Seeds of muskmelon, cvs. Mission and Top Net SR were artificially aged at $43^{\circ} \mathrm{C}$ for 0,20 and 40 hours. Seeds were primed for six days in darkness at $25^{\circ} \mathrm{C}$ in $\mathrm{KNO}_{3}\left(0.35 \mathrm{~mol} \mathrm{~L}^{-1}\right)$ aerated solution. Aged seeds germinated poorly at $17^{\circ} \mathrm{C}$. Priming increased germination rate at 17 and $25^{\circ} \mathrm{C}$ and germination percentage at $17^{\circ} \mathrm{C}$. An interaction effect on germination performance between vigor and priming was observed, especially at low temperature. Priming increased germination performance in seeds of low vigor, and the response was cultivar dependent.
\end{abstract}

Key words: germination, osmoconditioning, cultivars, stand establishment

\section{CONDICIONAMENTO OSMÓTICO DE SEMENTES DE MELÃO EM RELAÇÃO AO VIGOR}

\begin{abstract}
RESUMO: A resposta do condicionamento osmótico pode ser afetada por importantes fatores, incluindo a qualidade das sementes. Efeitos no vigor de sementes em resposta ao condicionamento osmótico foram investigados utilizando diferentes lotes de duas cultivares de melão (Cucumis melo L.). Sementes de melão cvs. Mission e Top Net SR foram artificialmente envelhecidas a $43^{\circ} \mathrm{C}$ por 0,20 e 40 horas. Sementes foram osmoticamente condicionadas por seis dias no escuro a $25^{\circ} \mathrm{C}$ em solução aerada de $\mathrm{KNO}_{3}\left(0.35 \mathrm{~mol} \mathrm{~L}^{-1}\right)$. Sementes envelhecidas apresentaram uma baixa germinação a $17^{\circ} \mathrm{C}$. O condicionamento osmótico aumentou a velocidade de germinação a 17 e $25^{\circ} \mathrm{C}$ e a porcentagem de germinação a $17^{\circ} \mathrm{C}$ foi observada interação significativa na germinação entre o vigor das sementes e o condicionamento especialmente em condições de baixas temperaturas. O condicionamento osmótico melhorou o desempenho da germinação das sementes de baixo vigor, e a resposta foi dependente da cultivar.

Palavras-chave: germinação, cultivares, estabelecimento de plântulas
\end{abstract}

\section{INTRODUCTION}

Seed priming is a pre-sowing treatment that involves the controlled hydration of seeds, sufficient to allow pre-germinative metabolic events to take place but insufficient to allow radicle protrusion through the seed coat (Heydecker et al., 1973). This technique has been used in some vegetable seeds to increase the germination rate, total germination and seedling uniformity, mainly under unfavorable environmental conditions. Beneficial effects of seed priming have been reported for melon (Cucumis melo L.) by Bradford (1985), Nerson \& Govers (1986), Bradford et al. (1988), Passam et al. (1989), and Nascimento \& West $(1998 ; 1999)$.

A number of important factors may affect seed priming response, including seed quality (Parera \& Cantliffe, 1994). Therefore, the response to seed priming treatments may vary among seed lots (Brocklehurst \& Dearman, 1983) because of differences in seed vigor. A strong interaction was observed between pepper seed lots and priming response, with the slowly germinating lots exhibiting the greatest benefit from priming (Bradford et al., 1990). The effectiveness of priming to improve the germination performance of tomato aged seeds depended on the degree of seed deterioration (Alvarado \& Bradford, 1988a; 1988b). However, there is some inconsistency in the results of seed vigor studies.

For carrot, Cantliffe \& Elballa (1994) recommended the use of high quality seeds to obtain the best results from priming, whereas for leek, Bray (1995) verified that priming increased germination performance of low vigor seeds. For lettuce, Perkins-Veazie \& Cantliffe (1984) observed beneficial effects of priming only for nonaged seeds. In addition, high seed vigor is necessary for tolerance to environmental stress (Heydecker, 1972). For example, improved seedling emergence and uniformity of preconditioned lettuce seeds at high temperature was related to high vigor (Perkins-Veazie \& Cantliffe, 1984). This study investigated the effects of muskmelon seed vigor in response to seed priming. 


\section{MATERIAL AND METHODS}

Seeds of two cultivars of muskmelon Top Net SR and Mission, were artificially aged at $43^{\circ} \mathrm{C}$ and $100 \% \mathrm{RH}$ for 0, 20 and 40 hours and then dried for two days under laboratory conditions $\left(20-25^{\circ} \mathrm{C}\right)$, generating three separate lots from each cultivar. Half of each lot remained untreated and half was primed for 6 days in the dark at $25^{\circ} \mathrm{C}$ in $\mathrm{KNO}_{3}\left(0.35 \mathrm{~mol} \mathrm{~L}^{-1}\right)$, in an aerated solution (10 $\mathrm{mL}$ solution $\mathrm{g}^{-1}$ of seed). The air was pre-hydrated through bubbling in water to minimize evaporation of the soaking solution. The solution was changed every other day. After this period, seeds were rinsed in running, tap water ( $2 \mathrm{~min}$ ) and redried in the laboratory (20$25^{\circ} \mathrm{C}$ ) for 2 days. Germination was tested using four replications of 25 seeds placed in $15 \mathrm{~cm}$ Petri dishes containing two papers moistened with $10 \mathrm{~mL}$ of deionized water and incubated in a germination chamber, in the dark. Germination was assessed at 17 and $25^{\circ} \mathrm{C}$. Radicle protrusion was scored daily and the germination rate (mean days to germination) was calculated according to the formula $\Sigma(\mathrm{Ti} \mathrm{Ni}) / \Sigma \mathrm{Ni}$, where $\mathrm{Ni}$ is the number of newly germinated seeds at day Ti (Maguire, 1962). After seven and 14 days of incubation at 25 and $17^{\circ} \mathrm{C}$, respectively, seedlings were evaluated according to rules of the Association of Official Seed Analysts (AOSA, 1993). Analysis of variance and factorial analysis were performed using the Statistical Analysis System (SAS Institute, Inc., 1988).

\section{RESULTS AND DISCUSSION}

\section{Mission cultivar}

Germination percentage at $25^{\circ} \mathrm{C}$ did not differ among aging treatments (Table 1); however, germination rate decreased with aging of 20 and 40 hours as compared to the control. Priming did not affect germination percentage of aged seeds at $25^{\circ} \mathrm{C}$, but increased germination rate. At $17^{\circ} \mathrm{C}$, seeds aged for 20 hours had reduced germination and seeds aged for 40 hours and not primed did not germinate (Table 1). Priming increased both the germination percentage and germination rate of unaged and aged seeds at $17^{\circ} \mathrm{C}$. These priming benefits might be observed in the conditions of the Southern regions of Brazil, where temperatures are very low during winter. In these regions, Biasi (1994) recommend the use of muskmelon transplants, produced under controlled conditions, to avoid the adverse effects of low temperature.

The increase in germination and the differences in germination performances among the seed lots were not observed after priming, especially under adverse temperatures (Table 1). For example, low vigor (40 houraged) unprimed seeds did not germinate at $17^{\circ} \mathrm{C}$, and 20 hour-aged, unprimed seeds germinated only $30 \%$, whereas primed seeds aged for 20 and 40 hours germinated 95 and $97 \%$, respectively.

\section{Top Net SR cultivar}

The differences among seed vigor levels were observed more clearly for this cultivar in relation to the

Table 1 - 'Mission' muskmelon unprimed and primed seed germination (GT) and germination rate (GR) at two temperatures and different seed aging levels.

\begin{tabular}{|c|c|c|c|c|c|}
\hline \multirow[b]{3}{*}{ Factor } & \multirow[b]{3}{*}{ Treatment } & \multicolumn{4}{|c|}{ Temperature $\left({ }^{\circ} \mathrm{C}\right)$} \\
\hline & & \multicolumn{2}{|c|}{17} & \multicolumn{2}{|c|}{25} \\
\hline & & GR & GT & GR & GT \\
\hline \multirow{4}{*}{ Aging (hours) } & & days & $\%$ & days & $\%$ \\
\hline & 0 & $4.3 \mathrm{c}$ & $95 \mathrm{a}$ & $1.4 \mathrm{~b}$ & $99 \mathrm{a}$ \\
\hline & 20 & $6.1 \mathrm{~b}$ & $62 \mathrm{~b}$ & $1.5 \mathrm{a}$ & $100 \mathrm{a}$ \\
\hline & 40 & $7.1 \mathrm{a}$ & $48 \mathrm{c}$ & $1.5 \mathrm{a}$ & $100 \mathrm{a}$ \\
\hline LSD* & & 0.55 & 6.40 & 0.07 & 1.52 \\
\hline \multirow{2}{*}{ Seeds } & Primed (P) & $3.6 \mathrm{~b}$ & $97 \mathrm{a}$ & $1.0 \mathrm{~b}$ & 99 a $r a$ \\
\hline & Unprimed (U) & $8.1 \mathrm{a}$ & $41 \mathrm{~b}$ & $1.9 \mathrm{a}$ & $100 \mathrm{a}$ \\
\hline LSD* & & 1.57 & 30.67 & 0.07 & 1.28 \\
\hline \multirow{6}{*}{ Interaction } & $0 \times \mathrm{P}$ & $3.4 \mathrm{~d}$ & $98 \mathrm{a}$ & $1.0 \mathrm{~b}$ & $98 \mathrm{a}$ \\
\hline & $0 \times \mathrm{U}$ & $5.2 \mathrm{~b}$ & $92 \mathrm{a}$ & $1.9 \mathrm{a}$ & $100 \mathrm{a}$ \\
\hline & $20 \times \mathrm{P}$ & $3.2 \mathrm{~d}$ & $95 \mathrm{a}$ & $1.1 \mathrm{~b}$ & $100 \mathrm{a}$ \\
\hline & $20 \times U$ & $9.0 \mathrm{a}$ & $30 \mathrm{~b}$ & $2.0 \mathrm{a}$ & $100 \mathrm{a}$ \\
\hline & $40 \times \mathrm{P}$ & $4.2 \mathrm{c}$ & $97 \mathrm{a}$ & $1.0 \mathrm{~b}$ & $100 \mathrm{a}$ \\
\hline & $40 \times \mathrm{U}$ & - & $0 \mathrm{c}$ & $2.0 \mathrm{a}$ & $100 \mathrm{a}$ \\
\hline LSD* & & 0.78 & 9.04 & 0.10 & 2.14 \\
\hline
\end{tabular}

*Means within a column followed by the same letter were not different by Least Significant Difference (LSD) test, at $\alpha=0.05$. 
'Mission' cultivar. At $25^{\circ} \mathrm{C}$, germination and germination rate of unprimed seeds reduced with aging treatments (Table 2). Priming increased germination rate at $25^{\circ} \mathrm{C}$. Seeds from all treatments germinated poorly at $17^{\circ} \mathrm{C}$ and seeds aged for 40 hours and untreated failed to germinate (Table 2). Priming increased germination of aged seeds, but not as high as for the unaged seeds. For example, unaged seeds germinated $92 \%$, whereas 20 - and 40- hour-aged primed seeds germinated 62 and 68\%, respectively.

Aged (low vigor) seeds germinated poorly at $17^{\circ} \mathrm{C}$. These results support the fact that high seed vigor is responsible for tolerance to environmental stress (Heydecker, 1972), including low temperatures. The response of aging might be related to not only the cultivar differences but also to seed quality; a greater reduction in seed quality due to aging occurred for 'Top Net SR' seeds in relation to 'Mission'. Differences observed in the germination rate from the two cultivars suggest that the seed quality of the 'Mission' cultivar could explain this (Tables 1 and 2).

Priming increased seed performance and reduced differences in seed quality. Priming increased germination rate of aged seeds at both temperatures and the total germination at $17^{\circ} \mathrm{C}$. In general, the effects of seed priming on muskmelon seed germination have been mainly observed for sub-optimal conditions (Bradford, 1985; Bradford et al., 1988), and this was confirmed in this study. However, Nerson \& Govers (1986) found that the response of priming was cultivar-dependent; using the 'Persia 202' cultivar the beneficial effects of low temperature germination were maintained, whereas using 'Noy Yizre'el', the germination was reduced. In another study, priming affected muskmelon seeds differently, depending on their stage of development (Welbaum \& Bradford, 1991).

However, Nascimento \& West (2000) reported the importance of drying conditions during seed priming and that the main benefits of using muskmelon primed seeds (i.e, germination at low temperature) may be lost following unfavorable drying conditions. In addition, Oluoch \& Welbaum (1996a; 1996b) found that priming was deleterious for 'Top Mark' muskmelon seed longevity. For tomato, the enhancement of seed germination rate by priming treatments lowered the resistance of seeds in relation to deterioration (Argerich et al., 1989). However, priming may unchange, reduce or improve seed quality, depending on the seed vigor criteria used in these studies (Argerich \& Bradford, 1989).

The improvement in germination performance resulting from priming treatments has been suggested as a result of repair mechanisms that occur during soaking (Burgass \& Powell, 1984); the seeds during the maturation process and/or during storage deteriorate and need repair during imbibition in order to germinate (Osborne, 1983). Thus, aged (more deteriorated) seeds could benefit more from priming treatments.

Table 2 - 'Top Net' muskmelon unprimed and primed seed germination (GT) and germination rate (GR) at two temperatures and different seed aging levels.

\begin{tabular}{|c|c|c|c|c|c|}
\hline \multirow[b]{3}{*}{ Factor } & \multirow[b]{3}{*}{ Treatment } & \multicolumn{4}{|c|}{ Temperature $\left({ }^{\circ} \mathrm{C}\right)$} \\
\hline & & \multicolumn{2}{|c|}{17} & \multicolumn{2}{|c|}{25} \\
\hline & & GR & GT & GR & GT \\
\hline \multirow{4}{*}{ Aging (hours) } & & days & $\%$ & days & $\%$ \\
\hline & 0 & $6.1 \mathrm{c}$ & $67 \mathrm{a}$ & $1.7 \mathrm{~b}$ & $93 \mathrm{a}$ \\
\hline & 20 & $7.0 \mathrm{~b}$ & $32 \mathrm{~b}$ & $2.0 \mathrm{a}$ & $87 \mathrm{ab}$ \\
\hline & 40 & $8.0 \mathrm{a}$ & $34 \mathrm{~b}$ & $2.1 \mathrm{a}$ & $84 \mathrm{~b}$ \\
\hline LSD* & & 0.33 & 7.40 & 0.20 & 6.95 \\
\hline \multirow{2}{*}{ Seeds } & Primed $(\mathrm{P})$ & $4.9 \mathrm{~b}$ & $74 \mathrm{a}$ & $1.5 \mathrm{~b}$ & $87 \mathrm{a}$ \\
\hline & Unprimed (U) & $9.2 \mathrm{a}$ & $15 \mathrm{~b}$ & $2.4 \mathrm{a}$ & 89 a \\
\hline LSD* & & 1.05 & 8.54 & 0.16 & 5.80 \\
\hline \multirow{6}{*}{ Interaction } & $0 \times \mathrm{P}$ & $4.6 \mathrm{~d}$ & 92 a & $1.3 \mathrm{~d}$ & $90 \mathrm{ab}$ \\
\hline & $0 \times \mathrm{U}$ & $7.6 \mathrm{~b}$ & $43 \mathrm{c}$ & $2.2 \mathrm{~b}$ & 97 a \\
\hline & $20 \times \mathrm{P}$ & $4.1 \mathrm{e}$ & $62 \mathrm{~b}$ & $1.7 \mathrm{c}$ & $87 \mathrm{~b}$ \\
\hline & $20 \times \mathrm{U}$ & $10.0 \mathrm{a}$ & $2 \mathrm{~d}$ & $2.4 \mathrm{a}$ & $88 \mathrm{ab}$ \\
\hline & $40 \times \mathrm{P}$ & $6.1 \mathrm{c}$ & $68 \mathrm{~b}$ & $1.6 \mathrm{c}$ & $85 \mathrm{~b}$ \\
\hline & $40 \times \mathrm{U}$ & - & $0 \mathrm{~d}$ & $2.6 \mathrm{a}$ & $83 \mathrm{~b}$ \\
\hline LSD* & & 0.47 & 10.46 & 0.29 & 9.83 \\
\hline
\end{tabular}

*Means within a column followed by the same letter were not different by Least Significant Difference (LSD) test, at $\alpha=0.05$. 


\section{CONCLUSIONS}

Low vigor seeds of muskmelon can be primed in order to perform better under adverse conditions.

\section{REFERENCES}

ALVARADO, A.D.; BRADFORD, K.J. Priming and storage of tomato (Lycopersicon lycopersicum) seeds. I. Effects of storage temperature on germination rate and viability. Seed Science and Technology, v.16, p.601-612, 1988a.

ALVARADO, A.D.; BRADFORD, K.J. Priming and storage of tomato (Lycopersicon lycopersicum) seeds. II. Influence of a second treatment after storage on germination and field emergence. Seed Science and Technology, v.16, p.613-623, 1988b.

ARGERICH, C.A.; BRADFORD, K.J. The effects of priming and ageing on seed vigour in tomato. Journal of Experimental Botany, v.40, p.599607,1989

ARGERICH, C.A.; BRADFORD, K.J.; TARQUIS, A.M. The effects of priming and ageing on resistance to deterioration of tomato seeds. Journal of Experimental Botany, v.40, p.593-598, 1989.

ASSOCIATION OF OFFICIAL SEED ANALYSIS. Rules for testing seeds. Journal of Seed Technology, v.16, p.1-113, 1993.

BIASI, J. Orientações técnicas para o cultico de melões catarinenses. Agropecuária Catarinense, v.7, p.11-12, 1994.

BRADFORD, K.J. Seed priming improves germination and emergence of cantaloupe at low temperature. HortScience, v.20, p.598, 1985.

BRADFORD, K.J.; STEINER, J.J.; TRAWATHA, S.E. Seed priming influence on germination and emergence of pepper seed lots. Crop Science, v.30, p.718-721, 1990.

BRADFORD, K.J.; MAY, D.M.; HOYLE, B.J.; SIBINSKI, S.; SCOTT, S.J; TYLER, K.B. Seed and soil treatments to improve emergence of muskmelon from cold or crusted soils. Crop Science, v.28, p.1001-1005, 1988.

BRAY, C.M. Biochemical processes during the osmopriming of seeds. In: KIGEL, J.; GALILI. G. (Ed.) Seed development and germination. New York: Marcel Dekker, 1995. p.767-789.

BROCKLEHURST, P.A.; DEARMAN, J. Interactions between seed priming treatments and nine seed lots of carrot, celery and onion: I. Laboratory germination. Annals of Applied Biology, v.102, p.577-584, 1983.

BURGASS, R.W.; POWELL, A.A. Evidence for repair processes in the invigoration of seeds by hydration. Annals of Botany, v.53, p.753-757, 1984.

CANTLIFFE, D.J.; ELBALLA, M. Improved germination of carrot at stressful high temperature by seed priming. Proceedings of the Florida State Horticultural Society, v.107, p.121-128, 1994.
HEYDECKER, W. Vigor. In: ROBERTS, E.H. Viability of seeds. Syracuse: Syracuse University Press, p.209-252, 1972.

HEYDECKER, W.; HIGGIS, J.; GULLIVER, R.L. Accelerated germination by osmotic treatment. Nature, v.246, p.42-44, 1973.

MAGUIRE, J.D. Seeds of germination-aid in selection and evaluation for seedling emergence and vigor. Crop Science, v.2, p.176-177, 1962.

NASCIMENTO, W.M.; WEST, S.H. Priming and seed orientation affect seed coat adherence and seedling development of muskmelon transplants. HortScience, v.33, p.847- 848, 1998.

NASCIMENTO, W.M.; WEST, S.H. Muskmelon transplant in response to seed priming. Hort Technology, v.9, p.53-55, 1999.

NASCIMENTO, W.M.; WEST, S.H. Drying during muskmelon (Cucumis melo L.) seed priming and its effects on seed germination and deterioration. Seed Science and Technology, v.28, p.211-215, 2000.

NERSON, H.; GOVERS, A. Salt priming of muskmelon seeds for lowtemperature germination. Scientia Horticulturae, v.2, p.85-91, 1986.

OLUOCH, M.O.; WELBAUM, G.E. Effect of postharvest washing and poststorage priming on viability and vigour of six-year-old muskmelon (Cucumis melo L.) seeds from eight stages of development. Seed Science and Technology, v.24, p.195-209, 1996a.

OLUOCH, M.O.; WELBAUM, G.E. Viability and vigor of osmotically primed muskmelon seeds after nine years of storage. Journal of the American Society for Horticultural Science, v.121, p.408-413, 1996b.

OSBORNE, D.J. Biochemical control of systems operating in the early hours of germination. Canadian Journal of Botany, v.61, p.3568-3577, 1983.

PARERA, C.A.; CANTLIFFE, D.J. Presowing seed priming. Horticultural Reviews, v.16, p. 109-139, 1994.

PASSAM, H.C.; KARAVITES, P.I.; PAPANDREOU, A.A.; THANOS, C.A.; GEORGHIOU, K. Osmoconditioning of seeds in relation to growth and fruit yield of aubergine, pepper, cucumber and melon in unheated greenhouse cultivation. Scientia Horticulturae, v.38, p.217-216, 1989.

PERKINS-VEAZIE, P.; CANTLIFFE, D.J. Need for high-quality seed for effective priming to overcome thermodormancy in lettuce. Journal of the American Society for Horticultural Science, v.109, p.368-372, 1984.

SAS INSTITUTE. SAS/STAT User's guide. Release 6.0 3.ed. Cary: Statistical Analysis System Institute, 1988.

WELBAUM, G.E.; BRADFORD, K.J. Water relations of seed development and germination in muskmelon (Cucumis melo L.). VI. Influence of priming on germination responses to temperature and water potential during seed development. Journal of Experimental Botany, v.42, p.393399, 1991

Received January 06, 2003

Accepted October 23, 2003 